\title{
Thyroid-Stimulating Hormone, Prolactin, and Growth Hormone Response to Thyrotropin-Releasing Hormone in Treated Children with Congenital Hypothyroidism
}

\author{
JOSEPH SACK, YUVAL SHAFRIR, DALIA URBACH, AND ORA AMADO \\ Pediatric Endocrinology Unit, Institute of Endocrinology, Sheba Medical Center, Tel-Hasomer, Israel
}

\begin{abstract}
The purpose of the present study was to assess thyroid-stimulating hormone (TSH), prolactin, and growth hormone responses to TRH stimulation in 12 congenitally hypothyroid children adequately treated with $\mathrm{L}$ thyroxine from the first weeks of life. Although clinically euthyroid, six of these children were found to have abnormally high basal serum TSH concentrations despite clinical euthyroidism. Serum triiodothyroxine and L-thyroxine concentrations were normal and did not differ whether the children had elevated or normal basal serum TSH. All six of the children with high basal TSH had an exaggerated TSH response to TRH and 4 of them also had an augmented prolactin response to TRH. The children with normal basal TSH concentrations had normal TSH and prolactin responses to TRH. An abnormal ("paradoxical") elevation of growth hormone concentration in response to TRH was found in four of seven children in a separate group of patients who had prolonged, untreated primary hypothyroidism, but such responses were not found in any of the adequately treated children. These findings suggest the following conclusions: 1) the phenomenon of high serum concentrations of TSH in conjunction with normal L-thyroxine and triiodothyronine levels (and clinical euthyroidism), is prevalent in congenital hypothyroid patients. 2) These patients have an exaggerated response of their pituitary thyrotroph and lactotroph cells to TRH, presumably caused by selective and relative resistance of these cells to the inhibitory effects of thyroid hormones. 3) Congenital hypothyroidism is not associated with abnormal somatotroph cell responses to TRH. (Pediatr Res 19: 1037-1039, 1985)
\end{abstract}

\section{Abbreviations}

GH, growth hormone

PRL, prolactin

T3, triiodothyronine

T4, L-thyroxine

TRH, thyrotropin releasing hormone

TSH, thyroid stimulating hormone

CH, congenital hypothyroidism

In addition to elevated serum concentrations of TSH and an exaggerated response of TSH to TRH, other alterations in pitui-

Received November 5, 1984; accepted May 30, 1985.

Reprints Prof. J. Sack, c/o Kenneth D. Burman, M.D., Endocrine-Metabolic Service and Kyle-Metabolic Unit, Walter Reed Army Medical Center, Washington, D.C. 20011 tary regulation are well known in hypothyroid patients. Two examples of these alterations are the increased PRL response to TRH $(1,2)$ and the stimulation of GH secretion by TRH in hypothyroid children (3) and adults (4); these responses do not occur in normal subjects (5). It has been shown that many children suffering from congenital hypothyroidism manifest high serum TSH concentrations for prolonged periods despite adequate replacement therapy, clinical euthyrodism, and normal serum levels of thyroid hormones (7-10). It was suggested that this is due to an elevated threshold for thyrotroph cell TSH suppression by thyroid hormones. The purpose of the present study was to examine both the pituitary-thyroid negative feedback relationship and lactotroph and somatotroph regulation in children with congenital hypothyroidism.

\section{MATERIALS AND METHODS}

TRH tests were performed in 19 children. Group A consisted of 12 congenitally hypothyroid patients aged 1.6 to $9.3 \mathrm{yr}$ attending our clinic for congenital hypothyroidism. All were diagnosed by neonatal thyroid screening during the first weeks of life, and all were treated from the time of diagnosis with $\mathrm{T} 4$ and followed by one of us (J.S.). Serum T4 levels were normalized in, all children from the first month of treatment, and normal growth and development were observed. All group A children were clinically euthyroid for several months before the TRH test and had normal serum levels of thyroid hormones. Group B consisted of seven children, six girls, and one boy, aged 9 to $15.5 \mathrm{yr}$ with primary acquired hypothyroidism present for at least several months prior to the time of evaluation and initiation of thyroid hormone treatment.

All tests were performed after informed consent of the parents. The TRH stimulation test was performed between 0900 and $1200 \mathrm{~h}$, and the children were supine during the test. A short plastic catheter was inserted into an antecubital vein and normal saline solution was infused to maintain patency. Blood samples were obtained from the catheter upon insertion and every 15 to $30 \mathrm{~min}$ thereafter for $75 \mathrm{~min}$. Fifteen minutes after insertion of the catheter (time 0), $7 \mu \mathrm{g} / \mathrm{kg}$ body weight TRH (Hoechst) was injected intravenously.

Blood samples were centrifuged within $1 \mathrm{~h}$ of sampling, and plasma was immediately frozen at $-20^{\circ} \mathrm{C}$ until assayed. All serum samples were measured in duplicate in the same assay. GH was measured using the radioimmunoassay kit supplied by Serono Laboratories (Milan, Italy); lower limit of detection was $0.2 \mathrm{ng} / \mathrm{ml}$. Serum PRL was measured by radioimmunoassay using materials kindly supplied by NIH, NIADDK, Bethesda, MD; normal values less than $20 \mathrm{ng} / \mathrm{ml}$. Serum T4 (5 to $12 \mu \mathrm{g} /$ dl), T3 (120 to $220 \mathrm{ng} / \mathrm{dl}$ ), and TSH (normal values less than 6 $\mu \mathrm{U} / \mathrm{ml}$ ) were measured using radioimunoassay kits supplied by Diagnostic Products Corp. (Los Angeles, CA). 
Table 1. TSH, PRL, and GH responses to intravenous TRH in group Al children

\begin{tabular}{|c|c|c|c|c|c|c|c|c|c|c|c|c|c|c|c|c|}
\hline \multirow[b]{2}{*}{ No. } & \multirow[b]{2}{*}{ Sex } & \multirow{2}{*}{$\begin{array}{l}\text { Age } \\
(\mathrm{yr})\end{array}$} & \multirow{2}{*}{$\begin{array}{l}\mathrm{T} 4\left(0^{\prime}\right) \\
(\mu \mathrm{g} / \mathrm{dl})\end{array}$} & \multirow{2}{*}{$\begin{array}{l}\mathrm{T} 3\left(0^{\prime}\right) \\
\text { (ng/dl) }\end{array}$} & \multicolumn{4}{|c|}{$\mathrm{TSH}(\mu \mathrm{U} / \mathrm{ml})$} & \multicolumn{4}{|c|}{ PRL (ng/ml) } & \multicolumn{4}{|c|}{$\mathrm{GH}(\mathrm{ng} / \mathrm{ml})$} \\
\hline & & & & & $0^{\prime}$ & $15^{\prime}$ & $30^{\prime}$ & $60^{\prime}$ & $0^{\prime}$ & $15^{\prime}$ & $30^{\prime}$ & $60^{\prime}$ & $0^{\prime}$ & $15^{\prime}$ & $30^{\prime}$ & $60^{\prime}$ \\
\hline 1 & $\mathrm{~F}$ & 5.75 & 9 & 273 & 3.2 & 20 & 18.5 & 13 & 22 & 39 & 31 & 20 & 0.9 & 0.7 & 0.45 & 0.3 \\
\hline 2 & $\mathrm{~F}$ & 9.33 & 13 & 144 & 3.2 & 27 & 23 & 17.5 & 11 & 38 & 34 & 20 & 0.3 & 1.3 & 1 & 1.2 \\
\hline 3 & $\mathrm{~F}$ & 5.33 & 9.5 & 115 & 2.1 & 15 & 13 & 7 & 31 & 39 & 33 & 28 & 1.7 & 0.8 & 0.3 & 0.3 \\
\hline 4 & $\mathbf{M}$ & 3.25 & 12.1 & 207 & 1 & 13.5 & 14 & 5.6 & & & & & 1.6 & 2.3 & 1.4 & 1 \\
\hline 5 & $\mathrm{~F}$ & 6 & 12.2 & 167 & 4.1 & 16 & 19 & 19 & 11 & 32 & 23 & 19 & 3.2 & 1.0 & 0.4 & 0.3 \\
\hline 6 & M & 3 & 18.3 & 140 & 1 & 7.2 & 8.6 & 5.3 & 10 & 45 & 38 & 31 & 0.5 & 1.0 & 0.5 & 0.5 \\
\hline Mean & & 5.44 & 12.35 & 174 & 2.4 & 16.5 & 16 & 11.2 & 17 & 39 & 32 & 24 & 1.4 & 1.2 & 0.7 & 0.6 \\
\hline \pm SEM & & 0.9 & 1.38 & 23 & 0.5 & 2.7 & 2.1 & 2.5 & 4 & 2 & 2.5 & 2.5 & 0.5 & 0.2 & 0.2 & 0.2 \\
\hline
\end{tabular}

Table 2. TSH, PRL, and GH responses to intravenous TRH in group A2 children

\begin{tabular}{|c|c|c|c|c|c|c|c|c|c|c|c|c|c|c|c|c|}
\hline \multirow[b]{2}{*}{ No. } & \multirow[b]{2}{*}{ Sex } & \multirow{2}{*}{$\begin{array}{l}\text { Age } \\
(\mathrm{yr})\end{array}$} & \multirow{2}{*}{$\begin{array}{l}\left.\text { T4 (0 } 0^{\prime}\right) \\
(\mu / \mathrm{dl})\end{array}$} & \multirow{2}{*}{$\begin{array}{l}\mathrm{T} 3\left(0^{\prime}\right) \\
(\mathrm{ng} / \mathrm{dl})\end{array}$} & \multicolumn{4}{|c|}{$\operatorname{TSH}(\mu \mathrm{U} / \mathrm{ml})$} & \multicolumn{4}{|c|}{ PRL (ng/ml) } & \multicolumn{4}{|c|}{$\mathrm{GH}(\mathrm{ng} / \mathrm{ml})$} \\
\hline & & & & & $0^{\prime}$ & $15^{\prime}$ & $30^{\prime}$ & $60^{\prime}$ & $0^{\prime}$ & $15^{\prime}$ & $30^{\prime}$ & $60^{\prime}$ & $0^{\prime}$ & $15^{\prime}$ & $30^{\prime}$ & $60^{\prime}$ \\
\hline 7 & M & 2.2 & 11.1 & 178 & 34 & 82 & 108 & 77 & 2.5 & 20 & 20 & 11.5 & 1.9 & 1.5 & 1.2 & 1.0 \\
\hline 8 & $\mathbf{M}$ & 5.2 & 10.3 & 150 & 28 & 101 & 114 & 64 & & & & & 6.3 & 3.1 & 1.0 & 0.3 \\
\hline 9 & M & 3.75 & 13.5 & 148 & 29 & 50 & 180 & 49 & 27.5 & 145 & 120 & 68 & 1.3 & 1.3 & 0.9 & 1.2 \\
\hline 10 & $\mathrm{~F}$ & 4.7 & 13.9 & 183 & 28 & 60 & 200 & 132 & 29 & 140 & 107 & 61 & 3 . & 2.5 & 2.3 & 1.2 \\
\hline 11 & $\mathrm{~F}$ & 1.7 & 11.2 & 146 & 11 & 35 & 129 & 60 & 9 & 59 & 50 & 34 & 2.2 & 3 & 2.8 & 1.8 \\
\hline 12 & M & 2.2 & 12.3 & 191 & 16.5 & 42 & 49 & 51 & 31 & 156 & 131 & & 1 & 0.9 & 1.1 & 0.6 \\
\hline Mean & & 3.2 & 12.05 & 166 & 24 & 62 & 130 & 72 & 20 & 104 & 86 & 44 & 2.6 & 2.1 & 1.6 & 1 \\
\hline \pm SEM & & 0.6 & 0.6 & 8.2 & 3.6 & 10.3 & 22 & 12.7 & 6 & 27 & 21 & 13 & 0.8 & 0.4 & 0.3 & 0.2 \\
\hline
\end{tabular}

The normal plasma TSH concentration after 1 month of age is less than $6 \mu \mathrm{U} / \mathrm{ml}$, and the normal TSH response to TRH is at least twice the basal concentration, but not exceeding $35 \mu \mathrm{U} /$ $\mathrm{ml}$ [in agreement with previous reports (11)]. An abnormal ("paradoxical") plasma GH elevation after TRH injection was defined as at least twice the basal concentration (and above 5 $\mathrm{ng} / \mathrm{ml}$ ) as reported previously (3).

Statistical analyses were performed using Student's $t$ test for paired and unpaired data. All values are recorded as mean and SEM.

\section{RESULTS}

The children in group A were divided into two subgroups, A1 and A2 (Table 1). A1 consisted of children with basal TSH concentrations below $5 \mu \mathrm{U} / \mathrm{ml}$; children in group A2 had basal TSH levels greater than $10 \mu \mathrm{U} / \mathrm{ml}$. The children of subgroup A2 were slightly younger than those of subgroup $\mathrm{A} 1$, but the age difference is not statistically significant (Table 2). The concentrations of T3 and T4 in each subgroup were close to the upper limit of the normal range. The mean concentrations of $\mathrm{T} 3, \mathrm{~T} 4$, mean basal PRL, and GH did not differ statistically in the two subgroups (Fig. 1).

There was a marked difference in the TSH and PRL responses to TRH in the two subgroups. All children of subgroup A1 with normal basal TSH concentrations responded to TRH with a normal elevation of TSH (mean peak value at $15 \mathrm{~min}, 16.5 \pm$ $2.7 \mu \mathrm{U} / \mathrm{ml}$ ) and PRL (mean peak value at $15 \mathrm{~min}, 38.6 \pm 2.7$ $\mathrm{ng} / \mathrm{ml}$ ). The children of subgroup A2 responded to TRH with an exaggerated elevation of TSH (mean peak value at $30 \mathrm{~min}$, $130 \pm 22 \mu \mathrm{U} / \mathrm{ml}$ ). Four of group A2 children also demonstrated an exaggerated PRL response (mean peak value of the entire subgroup at $15 \mathrm{~min}, 104 \pm 27 \mathrm{ng} / \mathrm{ml})$. There was no increase in serum GH concentrations in response to TRH in any of the 12 A group children.

The mean T4 and T3 concentrations in seven children with prolonged primary congenital hypothyroidism (group B) were very low $(1.9 \pm 0.4$ and $67 \pm 15$, respectively). The mean basal TSH levels were very high (mean $307 \pm 93 \mu \mathrm{U} / \mathrm{ml}$ ) with an exaggerated TSH response (48 to $1200 \mu \mathrm{U} / \mathrm{ml}$ ), and both the
Table 3. The $G H$ response to $T R H$ in group $B$ children

\begin{tabular}{ccccccc}
\hline & \multirow{2}{*}{$\begin{array}{c}\text { Age } \\
\text { No. }\end{array}$} & & \multicolumn{4}{c}{$\mathrm{GH}(\mathrm{ng} / \mathrm{ml})$} \\
\cline { 4 - 7 } \cline { 4 - 7 } & & Sex & $0^{\prime}$ & $15^{\prime}$ & $30^{\prime}$ & $60^{\prime}$ \\
\hline 2 & 9.2 & $\mathrm{~F}$ & 0.4 & 2.8 & 1.1 & 0.5 \\
3 & 11 & $\mathrm{~F}$ & 1.1 & 6.4 & 8 & 1.3 \\
4 & 11.6 & $\mathrm{~F}$ & 1.2 & 5.9 & 5.3 & 11.2 \\
5 & 11.8 & $\mathrm{~F}$ & 1.0 & 0.2 & 0.5 & 2.5 \\
6 & 15.6 & $\mathrm{~F}$ & 2.3 & 4.3 & 3.7 & 3.0 \\
7 & 12 & $\mathrm{~F}$ & 3.9 & 6.9 & 17.3 & 5.2 \\
& 9.6 & $\mathrm{M}$ & 2.3 & 7.5 & 13 & 7.5 \\
Mean & 11.5 & & 1.8 & 4.9 & 7.0 & 4.5 \\
\pm SEM & 0.8 & & 0.4 & 1.0 & 2.4 & 1.4 \\
\hline
\end{tabular}

mean basal TSH level and the TSH response to TRH were significantly greater than in subgroup A2 children $(p<0.01)$.

The mean basal PRL concentration in group B children was higher, but not significantly so, than in subgroups $\mathrm{A} 1$ and $\mathrm{A} 2$. The PRL response to TRH was exaggerated in group B (mean peak value at $30 \mathrm{~min} .134 \pm 69 \mathrm{ng} / \mathrm{ml}$ ), similarly to the response in subgroup A2. Four of the 7 children of group B responded to TRH with an abnormal elevation of serum GH (Table 3).

\section{DISCUSSION}

In six of the 12 congenitally hypothyroid group A children who had been adequately treated with thyroxine from the first weeks of life (subgroup A2), a high basal serum TSH and exaggerated TSH and PRL responses to TRH were found. In these children T4 and T3 levels were in the upper normal range and were similar to values in the six subgroup A1 children with normal basal TSH and normal TRH-stimulated TSH and PRL responses. This phenomenon of high serum TSH concentrations despite clinical and biochemical euthyroidism (7-10) may be described as "selective relative resistance of the thyrotroph to the negative feedback effect of thyroid hormones" (12). It is "selective" because the peripheral tissues respond normally to thyroid hormones as reflected by clinical euthyroidism, and "relative" 


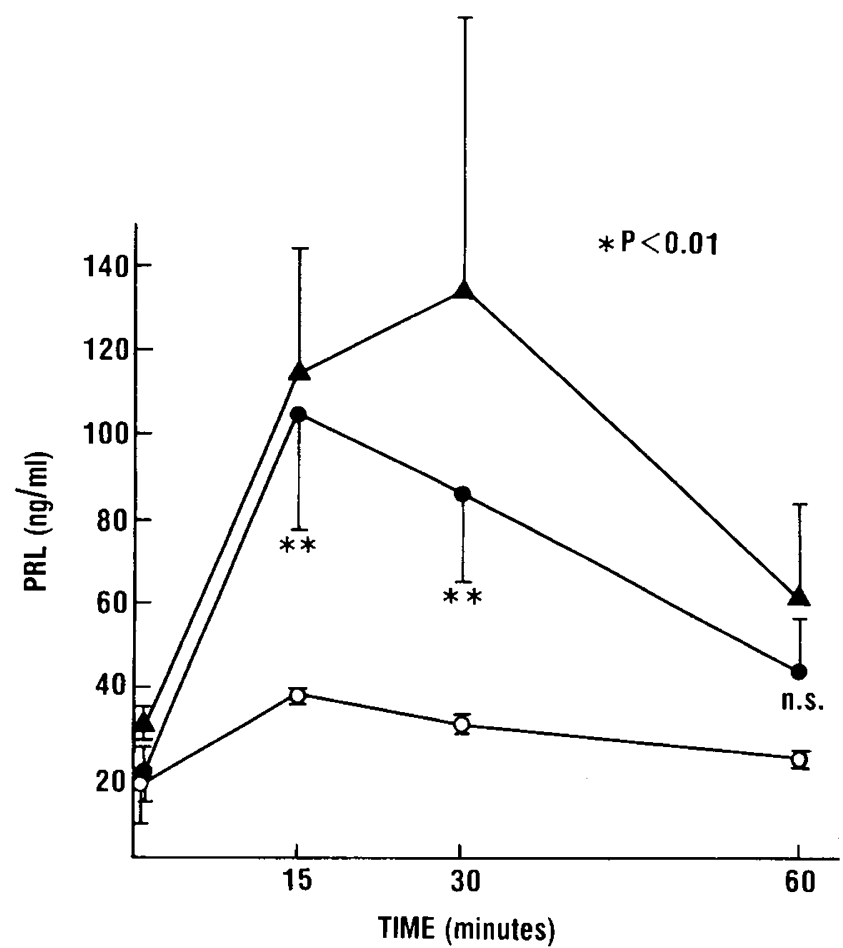

Fig. 1. PRL responses to intravenous TRH in children of subgroup A1 (open circles), subgroup A2 (closed circles), and group B (triangles). The Group $B$ values at 15,30 , and 60 min differ significantly from the A1 values $(p<0.01)$. The A2 values at 15 and $30 \mathrm{~min}$ also differ significantly from the Al values $(* * p<0.01)$.

because excessive TSH secretion can usually be suppressed when the child is made hyperthyroid with excessive doses of T4 (our unpublished data).

The present results show that resistance to the negative feedback effects of thyroid hormones in infants with congenital hypothyroidism, as reflected by exaggerated responses to exogenous TRH, is not limited to the thyrotroph cell, but also involves the lactotroph. In contrast, the somatotrophs responded normally in all group A children; the normal tendency of serum GH to decrease after TRH administration (3) was observed. Four of the seven children with prolonged, untreated, acquired, primary hypothyroidism (group B) responded with abnormal ("paradoxical") elevation in serum GH concentrations after TRH. This response has been reported previously in hypothyroid children (3) and adults (4). The cause for the paradoxical $\mathrm{GH}$ response in hypothyroidism is not known. It might be an expression of a regulatory reaction to the hyperactivity of the $\mathrm{GH}$ system characteristic of this state (14-16). According to this concept, restoring the $\mathrm{GH}$ pituitary reserve and normalizing the production of somatomedins abolishes the paradoxical response to TRH. In several reports it has been shown that the decline in pituitary GH concentration occurs only in severe prolonged hypothyroidism and that even suboptimal replacement of thyroid hormones rapidly restores $\mathrm{GH}$ concentration in the rat $(15,17)$. In any case, the subtle regulatory changes causing exaggerated TSH and PRL responses to TRH are independent of this $\mathrm{GH}$ response.

The pathophysiologic mechanism(s) causing the resistance of pituitary thyrotrophs and lactotrophs to the inhibitory effect of thyroid hormones is not clear. Hypothyroidism affects both the hypothalamus and the pituitary causing alteration in the structure $(18,19)$ and function $(20-22)$ of several pituitary cells, as well as alterations in secretion of selected hypothalamic regulatory peptides (23) in laboratory animals. It is suggested that in cases of congenital hypothyroidism some of these changes may persist despite adequate replacement therapy; in such infants there might have been an abnormal maturation of the hypothalamic-pituitary axis in a hypothyroid milieu.

\section{REFERENCES}

1. Foley TP Jr, Jacobs LS, Hoffman W, Daughaday WH, Blizzard RM 1972 Human prolactin and thyrotropin concentrations in the serums of normal and hypopituitary children before and after the administration of synthetic thyrotropin-releasing hormone. J Clin Invest .51:2143-2150

2. Suter SN, Kaplan SL, Aubert ML, Grumbach MM 1978 Plasma prolactin and thyrotropin and the response to thyrotropin releasing factor in children with primary and hypothalamic hypothyroidism. J Clin Endocrinol Metab 47:1015-1020

3. Collu R, Le Boeuf G, Letarte J, Ducharme JR 1977 Increase in plasma growth hormone levels following thyrotropin releasing hormone injection in children with primary hypothyroidism. J Clin Endocrinol Metab 44:743-747

4. Hamada N, Uoi K, Nishizawa $Y$, Okamoto $T$, Hasegawa K, Moria $H$, and Wada M 1976 Increase of serum GH concentrations following TRH injection in patients with primary hyothyroidism. Endocrinol Jpn 23:5-10

5. Anderson MS, Bowers CY, Kastin AJ, Schalch DS, Schally AV, Snyder PJ, Utiger RD, Wilber JF, Wise AJ 1971 Synthetic thyrotropin releasing hormone-a potent stimulator of thyrotropin secretion in man. N Engl J Med 285:1279-1283

6. Loosen PT, Mason GA, Prange AJ 1982 The TRH test in normal subjects: methodological consideration. Psychoneuroendocrinology 7:147-153

7. Sato T, Suzuki Y, Taketani T, Ishiguro K, Nakajima H 1977 Age related changes in pituitary threshold for TSH release during thyroxine replacement therapy for cretinism. J Clin Endocrinol Metab 44:553-559

8. Schultz RM, Glassman MS, MacGillivary MH 1980 Elevated threshold for thyrotropin suppression in congenital hyothyroidism. Am J Dis Child 134:19-20

9. Redmond GP, Soyka LF 1981 Abnormal TSH secretory dynamics in congenital hypothyroidism. J Pediatr 98:83-85

10. McCrossin RB, Sheffield LJ, Robertson EF 1980 Persisting abnormality in the pituitary-thyroid axis in congenital hypothyroidism. In: Stockigt JR, Nagataki S (eds) Thyroid Research VII. J Australian Academy of Science, Canbera, pp 37-40

11. Root AW, Rettig K, Vargas A, Reiter E 1979, The thyroid: recent advances in normal and abnormal physiology. Adv Pediatr 26:441-534

12. Refetoff $S 1982$ Syndromes of thyroid hormone resistance. Am J Physiol 243:E88-98

13. Scanlon MF, Lewis M, Weightman DR, Chan V, Hall R 1980 The neuroregulation of human thyrotropin secretion. Frontiers Neuroendocrinol 6:333

14. Minozzi M, Faggiano M, Lombardi G, Carella C, Cresevolo T, Oliver C, Vague PH 1973 Somatotrophic and corticotrophic functions in primary hypothyroidism before and after thyroxine treatment. Acta Endocrinol 74:483-491

15. Coiro V, Braverman LE, Christianson D, Fang SL, Goodman MH 1979 Effects of hypothyroidism and thyroxine replacement on growth hormone in the rat. Endocrinology 105:641-646

16. Burstein PJ, Draznin B, Johnson CJ, Schalch DS 1979 The effect of hypothyroidism on growth, serum growth-hormone, the growth-hormone dependent somatomedin, insulin-like growth factor and its carrier protein in rats. Endocrinology 104:1107-1111

17. Hervas F, Morreale de Escobar G, Escobar Del Rey F 1975 Rapid effects of single small doses of L-thyroxine and triiodo-L-thyronine on growth hormone, as studied in the rat by radioimmunoassay. Endocrinology 97:91-101

18. Surks MI, De Fesi CR 1977 Determination of the cell number of each cell type in the anterior pituitary of euthyroid and hypothyroid rats. Endocrinology 101:946-958

19. Astier HS, De Fesi CR, Surks MI 1979 Kinetics of deoxyribonucleic acid synthesis and replication of thyrotrophs and somatotrophs during development of hypothyroidism and T3 treatment of hypothyroid rats. Endocrinology 106:1537-1547

20. De Lean A, Ferland L, Drovin J, Kelly PA, Labrie F 1977 Modulation of pituitary thyrotropin-releasing hormone receptor levels by estrogens and thyroid hormones. Endocrinology 100:1496-1504

21. Hinkle PM, Goh KBC 1982 Regulation of thyrotropin-releasing hormone receptors and response by $\mathrm{T} 3$ in dispersed rat pituitary cell cultures. Endocrinology 110:1725-1731

22. Peck V, Gershengorn MC 1980 Differential regulation of the thyrotropinreleasing hormone receptors in neoplastic rodent mammotrophic, adrenocorticotrophic and thyrotrophic pituitary cells in culture. J Clin Endocrinol Metab 50:1144-1146

23. Berelowitz M, Maeda K, Harris S, Frohman LA 1980 The effect of alterations in pituitary/thyroid axis on hypothalamic content and in vitro release of somatostatin-like immunoreactivity. Endocrinology 107:24-29 